
vol. 1, 2010

\title{
EMOTIONAL ASPECT OF TEACHERS' PROFESSIONAL MASTERY IN LATVIA: THEORETICAL AND HISTORICAL REFLECTIONS
}

\author{
Inga Belousa and Skaidrīte Ūzuliṇa \\ Daugavpils University, Latvia
}

\begin{abstract}
Within the context of re-evaluation of teacher education to meet the challenges of globalisation, the discourse about holistic understanding of teacher's professional mastery is essential. The objective of this paper is to provide theoretical and historical reflections about teacher's professional mastery, highlighting the emotional aspect as a dimension that integrates all its levels. Theoretical and historical reflections in this study follow the methodology of discourse evaluation. The discourse is contextualized in a setting of three periods of time (the $1^{\text {st }}$ independence 1918-1940, Soviet occupation 1940-1990 and the $2^{\text {nd }}$ independence from 1990) and grounded in Latvian national and international perspectives. The study aims to deconstruct the cognitive competency-based view on teacher education and to provide reflections on teacher education that is teachers' self-based.
\end{abstract}

Key words: teacher's professional mastery, emotional aspect, teacher's competences, teacher's self, teacher education

\section{Introduction}

Discourse about a holistic understanding of teacher's professional mastery has been shaped by global philosophy and practice of reorienting teacher education towards sustainable development. Under the influence of globalisation, teacher's professional mastery ought to be regarded beyond the national and ethnical boundaries (Vīke-Freiberga, 2010), beyond particular professional skills or school subjects. The issue of teacher's professional mastery is widely discussed with extensive understandings and emphases. As Zeichner, Melnick and Gomez (1996) and Sherman (2004) have argued, it is insufficient to relate teaching only to technical aspects. Teacher's professional mastery that responds to contemporary challenges integrates several broad aspects, such as contemplation and imagination (Buchmann, 1988), caring and empathy (Noddings, 2003), thoughtfulness (Van Manen, 2002), discernment (Gallegos-Nava, 2001), cognition and emotion (Storbeck \& Clore, 2007) to mention but a few. The inner life of a teacher that implies hopes, beliefs, emotions, feelings and values (Sheri, 2008) should also be recognized as a crucial aspect of teacher's professional mastery. Thus, the discourse on a holistic understanding of teacher's professional mastery initiates recognition of the issues of authenticity of teacher's professional life and teacher's professional identity.

Currently in Latvia, discourse about teacher's professional mastery occurs both from a particular competence-based perspective (Maslo, 2006) and from a broader perspective 
where teacher's professional mastery is viewed holistically and related to identity (Pipere, 2007). In the general ecological theory (Wilber, 1997; Wilber, Patten, Leonard, \& Morelli, 2008), the explanation of holism is based on the systemic approach (Belickis, 2000). The emotional aspect of teacher's professional mastery is the precondition for creating the environment that is oriented towards the child's development and for the management of a conscious and systemic education where the child creates his/her knowledge, skills, attitudes and basic personality traits. The view on teacher's professional mastery as a set of technical competences is incomplete for shaping a sustainable society (Belickis, 2000), because under the dominance of the rational there is a lack of the whole-person perspective. In this article, a theoretical and historical study of the emotional aspect of teacher's professional mastery in Latvia is conducted by using the methodology of discourse evaluation (Bleakley, 2004) that follows a social constructionist view providing an analysis of the emotional aspect of teacher's professional mastery in the context of the historical, ethnographic, social, psychological and critical theory dimensions (Bleakley, 2004; Blommaert \& Bulcaen, 2000; Creswell, 1998; Fairclough, 2000). Discourse, in this paper, refers to a negotiated set of meanings that are both mediated and circumscribed by particular social, historical, political and other contexts. Discourse evaluation approach is applied to highlight that the considered sets of meanings are substantial keystones that shape educational reality within particular contexts, for instance, they denote how problems are defined, what options are preferred and what is implied by success or good practice in each period. Discourses in this paper are analysed in a deconstructive way to explore how they have came into being, how they initiate particular educational activities within a community of educators, how they legitimate or illegitimate particular educational practices.

The view on teacher's professional mastery in Latvia is contextualized in three periods since each of them gives a different outlook on teacher's professional mastery: the period of 1918-1940, the period of Soviet occupation during 1940-1990 and the contemporary period since 1990. This division ensures evaluation of teacher's professional mastery according to diverse historical contexts. The sources of information considered in this paper are varied: scientific theories and studies, materials from the Latvian State Historical Archives, which include normative educational documents and popular articles for mainstream educators, oral evidences, such as the life stories of people living during the period of the first independence of Latvia $(n=52)$ from the collection of the Centre of Oral History of Daugavpils University.

Considering the complexity of the concepts being discussed, this paper does not seek to define the major concepts, such as teacher's professional mastery and emotional aspect of teacher's professional mastery. Rather, it aims to highlight different assumptions that shape understanding of the major concepts in each period of time and to identify the assumptions that provide holistic understanding and sustainable representation of the considered concepts in educational practice. 


\section{Emotional aspect of pedagogical mastery in 1918-1940: Footprints of idealistic humanism, national romanticism and tacit authoritarianism}

The Latvian state and its education system developed under the conditions of the First World War. Since the establishment of the state, the economic, social and educational spheres had to be created anew. Such issues as illiteracy and poverty also needed to be addressed. At the dawn of the Republic of Latvia, the role of the school in developing national identity and national awareness was emphasized (Izglīin̄bas Ministrijas Mēnešraksts, 1921; Vīķe-Freiberga, 2010). Implicit reflections of the significance of the emotional aspect in teacher's professional mastery can be identified in the works of educators of that time - Dāle, Štāls, Dauge, Dēķens, Students, Pētersons, Seile, Ratnieks and others. At this period, discussions emerged about teacher's professional mastery, although pedagogical mastery and its emotional aspect were not yet explicitly defined.

Influenced by the Western European pedagogical thought, Latvian education authorities of that time emphasized the humanistic paradigm. Thus, philosophical ideas of humanists, for instance, Rousseau, Kerschensteiner, Montessori, Fröbel, Tolstoy, Ushinsky, who closely relate teacher's professional mastery to teacher's personality, highlighting the socio-emotional aspect and empathy - loving and understanding the child, promoting the child's growth with care that is regarded as the heart of creating a favourable, motivating the environment, were reflected in theoretical discourse shaped by Latvian educators.

Understanding of teacher's professional mastery can be implicitly inferred from the works of Pētersons (1931) and Štāls (1927), although they tend to focus on the way a pupil ought to do at school instead of what the teacher should be like. These sources, however, reveal the characteristics of teacher's professional mastery - teaching at school is not enough, the school should not only teach the child the 3 R's - reading, writing and arithmetic, but also educate them to be virtuous, honest and decent people. It was considered that teacher's personality is crucial in the child's development (Pētersons, 1931). Šāls indicated that "...educator ought to first and foremost be an idealist who devotes himself/herself to a worthy goal with all his/her heart and soul in order to be able to look into the child's soul and pull their heartstrings, so that educator's heartstrings resonate with the child's, and this amazing symphony plays on and on each and every moment" (Štāls, 1927, p. 14). The teacher is characterized as a social person whose soul incorporates an aspiration to live with people (Dāle, 1939; Dauge, 1928). Students (1933) posited that the secret of the growth of a teacher as a holistic person lies in an inner aspect of personality, thus beginning the discussion of the spiritual aspect in teacher's professional mastery. The teacher was valued as an advisor, facilitator, cooperation partner who understands the child's needs and provides emotional support. The public attitude towards the teacher was based on mutual respect and support. The socio-emotional aspect in teacher's professional mastery was grounded in the human meta-values - love that is manifested in attitude towards oneself and pupils (Pētersons, 1931, 1938, n.d.a, n.d.b, n.d.c; Ratnieks, 1940). Teacher's indifference and alienation in the teaching and upbringing processes were criticized. Teacher's professional mastery was perceived as the unity of professional knowledge, skills and teacher's personality traits, where the socio-emotional aspect - empathy - is manifested. 
The human paradigm emphasizes such notions as spirit, soul, understanding, compassion, solidarity and, in the contemporary perspective, is complemented with emotional intelligence (Goleman, 1995; Mayer, Salovey, Caruso \& Sitarenios, 2003; Mayer, Salovey, Caruso, 2004; Gardner, 2000). In the opinion of contemporary authors (Salowey \& Mayer, 1990), emotional intelligence is characterized by awareness of one's emotions, control over one's emotions, self-motivation, empathy, communication skills and ability to nurture other people's emotions. Contemporary authors evaluate the pedagogical ideas of this historical period regarding teacher's professional mastery and argue that the dominant educational approach in Latvia in the 1920s-1930s was the cognitive approach pupils making conclusions, learning by doing research (Belickis, 2000) that, in a sense, can be considered as the beginnings of action research in Latvia. Vỉke-Freiberga (2010) observes that the period from 1934 was marked by polemics in the sphere of the Latvian culture and education on the balance between Latvianness and internationality, characterized by levelling the Marxist populism and an authoritarian stance towards culture and education, with a strong critique of the aspects of democracy. Popularisation and support of the leading socio-political ideology were considered the main function of education and the main goal of upbringing at schools. Thus, this period cannot be judged unambiguously in what relates to the issue of teacher's professional mastery since it theoretically highlighted the importance of teacher's personality and, at the same time, was marked by tacit but perceptible authoritarianism.

Eyewitnesses' narratives confirm the practical activity manifestations of teacher's professional mastery during this historical period. These accounts are located in various archives, for instance, the Centre of Oral History of Daugavpils University (hereafter DU $\mathrm{COH}$ ) where one can find life story interviews relating to the sphere of education during this period in Latvia. The eyewitnesses' narratives highlight the manifestations of teacher's personality traits - empathy, emotional expression - in their professional mastery, especially in the interpersonal "pupil-teacher" communication. As Šeimans observes, "Teachers sometimes treated their pupils with irony if the latter understood or knew little. For instance, a biology teacher particularly ridiculed his pupils. They were called to the board and, in case of failing to answer, were ridiculed. Teachers emphasized that the most important things in life were knowledge and love for work." (Šeimans, 2003, January 9). Thus, although the theory was enriched with philosophical ideas of the idealistic humanism, the practice revealed a limited view of the components of educational content - emphasis on the knowledge and skills component and failing to underscore the attitude component which is based on the inner world and the emotional aspect.

As Grīnberga reveals, "Parents cooperated with the school, attended the school meetings and the parent's meetings. Parents required children to have a very serious attitude to school and teachers; everyone wanted their children to be educated" (Grīnberga, 2002, December 22). This observation suggests that the school and teachers were regarded by the nation as sources of knowledge and skills. This perspective could be explained by the influence of the ethnographic dimension - after gaining independence, the Latvians, originally a farming nation, felt the urge to leave the social stratum to which they were restricted over the centuries (Vīke-Freiberga, 2010). It also indicates that, at that time, education was considered a basic value. 
Examination of historical sources in the Latvian State Archives revealed that the pedagogical ideas of the period in question can be found in the Latvian Ministry of Education Monthly which published articles that supported the state socio-political ideology. Prior to publishing, the articles underwent strict reviewing and decisions were made as to their appropriateness and permission to be published (Vik ke-Freiberga, 2010). An analysis of archive materials (session protocols of the Ministry of Education) reveals that frequently some authors were banned from publishing for a particular period. Schools and other educational institutions were informed about the works of the Latvian authors that were forbidden to be included in the school curricula. This situation illustrates an authoritarian stance in educational policy, in accordance with the socio-political ideology. The ideas in the articles published in the Ministry of Education Monthly indicate that the essence of valuable education was perceived in the quest for truth in human activity, emotional experiences, self-transformation, national identity and the dimension of spirituality. Teacher's personality was particularly valued - the influence of intellectual, voluntary and emotional aspects in the organisation of the educational process. It was emphasized that the teacher ought to be a facilitator, advisor and co-worker who loves children (Pētersons, 1938, n.d.a, n.d.b, n.d.c; Ratnieks, 1940).

Žukovs and Kopeloviča (1997) state that, between 1920-1930, Latvia had four teacher training institutes - in Rīga, Daugavpils, Jelgava and Rēzekne. These institutions educated basic school teachers who were trained not only to perform their direct teaching duties, but also to become cultural workers - organize the cultural life of the local community. This is indicated in the "Law on the Nation's Education" (Likums par tautas izglitîbu, 1921), amended and ratified by the Latvian State Ministry of Education. The law describes the aims of teacher training institutes and the subjects to be taught there. The main aim of teacher education was to prepare teachers for work in folk schools. In order to reach the aim, future teachers had to maser the following study courses: religious studies, morals, native language, modern languages, history and social sciences, geography, mathematics, natural sciences with agronomy and hygiene, physics, chemistry with technology, calligraphy, drawing, technical drawing, modelling, singing and music, gymnastics, housekeeping (for girls), craft (for boys), psychology, pedagogy and subject methods. Thus, it can be indicated that teacher training was comprehensive in its nature since it integrated study courses from varied areas - arts, humanities, exact sciences, social sciences, pedagogy and psychology, although we cannot deny the presence of the atomistic approach in the organisation of teacher education. As reflected by Belousa (2005), education in Latvia was based on the synthesis of humanism and national romanticism, emphasising teacher's inner world and spirituality. Yet, Vīkse-Freiberga (2010) argues that acquisition of education, the range of the acquired knowledge, was not the crucial aspect which ensured that each graduate immediately became a renaissance person, a spiritual altruist and a humanist. This consideration reveals the crucial role of teacher's personality, the selfteacher, in developing teacher's professional mastery that is a universal frame of reference that exceeds contextual influence of history and nation.

In modern day terms, the teachers working at that time can be called media - the bearers of the ideas of independence, nationality, unity and education who are aware of their mission and ready to devote themselves to implementing it. 


\section{Emotional aspect of pedagogical mastery in 1940-1990: Deconstruction of national ideals and immersion in behaviourism and the Soviet ideology}

Since 1940 Latvia was incorporated in the Soviet Union. During this period that ended in 1990 , the field of education was complemented by various notions and terms from natural sciences. This tendency can be explained by the dominant pragmatist paradigm (Belickis, 2000). Higher education institutions and research centres that were established during the first independence of Latvia continued to exist, but research in social sciences was influenced by the Soviet ideology. It means that the content of education had lost its humanistic and existential basis; instead, it was grounded in the positivist philosophy and oriented towards personality development under the influence of socialist ideology (Ceruzis \& Stradiňš, 2000). The approach to teaching and upbringing was based on authoritarianism, and manifested in the use of destructive emotions. For instance, anger, contempt and threat could ensure discipline and order in the classroom. Teacher-centred approach and authoritarian relationships dominated in the educational process. The issues of emotionality and teacher's inner life contradicted the conception of communist ideology in education that, as Barghoorn and Reminghton (1986) put it, was based on three cornerstones of a single triangle: politically dogmatic instruction, work education and moral education. Within the pragmatist paradigm, discussion of the emotional aspect of teacher's professional mastery was sustained neither in philosophical nor in practical dimensions of teacher education or in education in general. Sources in this period related to education focused particularly on upbringing, on art in educational process and in extracurricular activities, for instance, organising hobby groups, pioneer camps, excursions, seminars, festivals, meetings with popular artists, excellent workers. Hiden and Salmon (1991) argue that these activities exemplify the influence modes of the covert political ideology that considered teacher's task to be that of representing the desirable reality of socialistic realism. Philosophy and practice of upbringing implied indirect concern for the emotional aspect in teacher's professional mastery, however, the emotional aspect, instead of collaboration, revealed the characteristics of the influence of persuasion instead of facilitation, using emotions as a means to an end.

Anspaks (2003) argues that this period led to destruction of the education system of the first independence period, eradicating its approaches and pedagogical ideals. Educators who still worked in the sphere of education could only retain the pedagogical ideals of the first independence period buried deep within their hearts (Belousa, 2005).

Teacher education in this period was based on the competence approach originated in the behaviouristic educational theory that was dominant at that time (Elliot, 1993, 2002; Elliot \& Kushner, 2007). Teachers were trained as technicians who can manage the teaching and learning process according to instructions and normative prescriptions. Yet, it was an incomplete fraction of pedagogical activity (Bel̦ickis, 2000), which nevertheless did not permit a holistic view on teacher's professional mastery. The normative, competencebased approach to teacher education contradicted the awareness of the emotional aspect in teacher's professional mastery.

Testimonies of teachers' and pupils' attitudes and communication, manifestations of teacher's professional mastery and the nature of teaching and upbringing abound in the 
eyewitnesses' memories. As Gol̦dina relates: “The teacher of the Latvian language, well, she scolded us something dreadful about our wrong pronunciation and our regional Latgalian accent during the lessons and even during recess... Rules to be followed at school were quite strict. Punishments for breaking the rules were diverse; we were made to stand in the hall..." (Golvdina, 2003, January 8). Goldina's experience points out the linear nature of teaching and upbringing, dominated by authoritarian communication where the teacher is regarded as pupils' natural enemy. It affirms that the educational process was based on the authoritarian teaching paradigm (Barr \& Tagg, 1995) whereas the emotional aspect and the role of teacher's personality became insignificant. The teaching paradigm permitted the use of destructive, negative emotions in the educational process. Authoritarian thinking presupposed support of a one single "right" truth, one "right" belief and one "right" action (Vìke-Freiberga, 2010). Such situation could lead to the awareness of a "false Self" when neither teachers nor pupils can implement the true purposes of their existence and are oriented towards creativity because of being used to deal with different situations in conformist circumstances. Authoritarian learning environment that disregarded the emotional aspect of teacher's professional mastery contradicted the preconditions of a safe and creative environment, directed towards fostering awareness of individual's personal identity, and therefore was not oriented towards sustainable development.

At this period, the teacher's image cannot be regarded unequivocally, considering the contemporary holistic perspective on teacher's professional mastery and synthesis of personality within it. This idea is confirmed by Rimša: "Relationships with teachers were different - there were these so-called strict teachers who frequently punished their pupils for failing to do their homework or learn the lesson, but then there were others, with whom I am still on friendly terms even now, long after graduation. They helped, they were benevolent..." (Rimša, 2002, December 22). The narrative suggests that emotional expression of teacher's personality, which manifests a natural desire to help pupils and take care of them, is crucial for meaningful education. Nevertheless, at this period, teacher's professional mastery was grounded in behaviouristic theory, thus contributing to a competence-based vision of pedagogical mastery.

\section{Emotional aspect of pedagogical mastery since 1990: Competence-based and identity-based perspectives}

Regaining national independence in 1990 caused significant changes in the national education system. The core principles of the Latvian state, education, science and culture developed during the initial years of the first independence and were deconstructed during the Soviet times. It was, therefore, necessary to re-evaluate and nationalize the education system, which had been common for the entire Soviet system during the Soviet period and totally renovate the system according to the principles of a democratic state. Educational reform was performed in the context of a paradigm shift (Belickis, 2000) from the traditional normatively-oriented paradigm to the human paradigm. The period witnessed reorientation from the authoritarian, normatively-oriented teaching process to a process where questions lack definite answers, where there is no single truth, no recipes for 
concrete actions (Belousa \& Stakle, 2007). Teacher-centred educational process was reoriented towards a child-centred educational process, and this reorientation was accompanied by changes in the teacher's role. Thus, the discussions of teachers' professional mastery, particularly in the first decade of this period, reflected the context of a paradigm shift.

Contemporary discourse in Latvia about teacher's professional mastery has a specific competence-based perspective (Maslo, 2006; Lieǵeniece, 2009; Andersone, 2009; Čehlovs \& Čehlova, 2009; Rutka, 2009) and a holistic perspective (Belousa, 2005; Pipere, 2007; Salīte, Mičule, Kravale, Iliško, \& Stakle, 2007). The competence-based perspective highlights the emotional aspect of teacher's professional mastery through the structure of teacher's professional competence: knowledge and skills. In the context of holism, the emotional aspect appears in the process of the development of teacher's professional identity. Thus, the current educational discourse in Latvia introduces a twofold view on teacher's professional mastery.

The discourse regarding teacher's professional mastery in Latvia is based on different educational theories - social cognitive educational theory (Bandura, 1988, 1989) and transformative educational theory (Mezirow, 1991, 2000; O'Sullivan, 2001). Social cognitive theory grounds teacher education and development of teacher's professional mastery in knowledge, personal experience and observations of colleagues' practical activity. A significant aspect for effective education is emotional connection with the observed and self-efficacy - whether the teacher believes in his or her ability to acquire certain behavioural norms. Mezirow $(1991,2000)$, as a theorist of transformative education, argues that socially cognitive educational theory is incomplete - any education entails change, but not all kind of change is transformation. Transformative educational theory views education comprehensively and holistically (Mezirow, 1991, 2000; O'Sullivan, 2001). In the context of transformative education, development of teacher's professional mastery can be described as a spiritual or emotional transformation through critical selfreflection and meta-analysis - transformation of deep emotional experience, knowledge and feelings into action, whereby a values system develops. Transformative education implies shaping of teacher's identity and mission, creating a link with the surrounding people, nature, events, etc. As Elliot puts it (Elliot, 1993, 2002; Elliot \& Kushner, 2007), learning is not an action, but a transaction, a process that involves emotional and intellectual synthesis. Nowadays, in the context of sustainable education, the discourse on the development of teacher's professional mastery via transformative education opens a holistic perspective on teacher's professional mastery.

Discourse on teacher's professional mastery is also affected by other education related disciplines, for instance psychology. Pedagogical psychology (Balsons, 1998; Geidžs \& Berliners, 1999) emphasizes inseparability of teacher's personality and professional mastery. Teacher's personality, int. al. its emotional aspect, directly influences pupils in the educational process. In pedagogical sources the emotional aspect is understood as emotional intelligence and empathy-based care (Brostrom, 2006). Care is perceived as specific relations between people when one individual affects the other; this relationship is grounded in whether and how one person supports the other's well-being, feels empathy and desire to help. Introducing the notion of emotional intelligence and encompassing in it 
self-control, diligence, persistence, ability to evaluate and guide one's actions, empathy and management of relationships (Goleman, 1995) initiates the extension of the view on teacher's professional mastery as a set of particular competences and skills. From the holistic perspective (Gallegos-Nava, 2001; Sheri, 2008), teacher's professional mastery underscores teacher self that is accessed through deep emotional reflection.

\section{Conclusions}

The discourse about teacher's professional mastery is affected by the leading national, socio-political and cultural context of the period and the educational theory dominant at a particular period of time. Also, the context of the leading philosophical paradigm of each historical period shapes the understanding of teacher's professional mastery. As it was discussed, during the period of 1918-1940, teacher's professional mastery was viewed through the paradigm of romanticism and idealistic humanism. The paradigm of this epoch was a precondition for emphasis on the humanistic values. During 1940-1990, teacher's professional mastery was contextualized in a normatively-oriented paradigm which is directed towards a behaviouristic, normatively-oriented, atomistic and competence-based approach. In the period from 1990 till nowadays, the twofold understanding of teacher's professional mastery reflects the context of a paradigm shift, thus both competence-based and identity-based understandings are present in educational discourse.

Currently, teacher's professional mastery in Latvia is characterized by two perspectives: the competence-based approach and the holistic approach. Taking into consideration that the context of post-modern paradigm highlights a holistic view on teacher's professional mastery, an identity-based understanding is rather compatible with postmodern educational discourse. Also, the context of sustainable education is a precondition for a holistic perspective on teacher's professional mastery and its development via transformative education for it initiates recognition of the authenticity of teacher's professional life and identity.

The contribution of discourse evaluation to the examination of the emotional aspect of teacher's professional mastery is the recognition that hidden assumptions and values uniquely characteristic to each period of time shape the conceptual and practical reality of education. Thus, to consider any concept, approach or an example of good practice, it has to be observed in connection with particular social, historical, political and other contexts.

Evaluation of the discourse on assumptions and values that shape education within particular contexts implies a comprehensive image of the major concepts discussed in this article. The importance of this discourse evaluation study is relevant to the current time of Bologna initiative in the European Higher Education Area that a teacher's input-focused traditional way should be redefined as based on an outcome-focused approach in terms of what learners are expected to achieve. Evaluation of the discourse on the emotional aspect of teacher's professional mastery can contribute to critical consideration of whether this aspect is recognized as a learning outcome and how it is reflected, intended to be taught and assessed in modules, courses and programs of teacher education and training. 


\section{Acknowledgment:}

This work has been supported by the European Social Fund within the Project "Support for the implementation of doctoral studies at Daugavpils University". Agreement $\mathrm{Nr}$. 2009/0140/1DP/1.1.2.1.2/09/IPIA/VIAA/015.

\section{References:}

Andersone, R. (2009). Skolotāju profesionālā kompetence sabiedrības ilgtspējīgai attīstībai [Teachers' professional competence for sustainable development of society]. In I. Žogla (Ed.), Latvijas Universitātes raksti: Pedagogija un skolotāju izglītība [Collected articles of the University of Latvia: Pedagogy and teacher education], Volume 747 (pp. 8-20). Rīga: Latgales druka.

Anspaks, J. (2003). Pedagogijas idejas Latvijā [Pedagogical ideas in Latvia]. Rīga: RaKa.

Balsons, M. (1998). Kā izprast klases uzvedību [How to understand pupils' behavior]. Rīga: Lielvārds.

Bandura, A. (1988). Organizational application of social cognitive theory. Australian Journal of Management, 13(2), 275-302.

Bandura, A. (1989). Human agency in social cognitive theory. American Psychologist, 44, 1175-1184.

Barghoorn, F., \& Remington, T. (1986). Politics in the USSR. Toronto: Little, Brown and Company.

Barr, R., \& Tagg, J. (1995). From teaching to learning - a new paradigm for undergraduate education. Change, 27(6), 12-26.

Belousa, I. (2005). Spirituality as a dimension of education: Reimaging and reconstructing teacher education in Latvia. Unpublished doctoral dissertation, Fordham University, New York, USA.

Belousa, I., \& Stakle, A. (2007). Development and reorientation of education toward sustainability in Latvia after 1991. In A. Pipere (Ed.), Education and Sustainable Development: First Steps toward Changes (Vol. 2, pp. 99-113). Daugavpils: Daugavpils University Publishing House "Saule".

Bel̦ickis, I. (2000). Vèrtīborientētā mācību stunda [Value-oriented lesson]. Rīga: RaKa.

Bleakley, A. (2004). Education research in the postmodern. Retrieved October 10, 2010 from http://www.edu.plymouth.ac.uk/resined/postmodernism/pmhome.htm\#CONT ENTS

Blommaert, J., \& Bulcaen, C. (2000). Critical discourse analysis. Annual Review of Anthropology, 29, 447-466.

Buchmann, M. (1988). Argument and contemplation in teaching. Oxford Review of Education, 14(2), 201-214.

Brostrom, S. (2006). Care and education: Towards a new paradigm in early childhood education. Child Youth Care Forum, 35, 391-409.

Ceruzis, R. \& Stradiņš, J. (2000). A brief history of education. Retrieved October 13, 2010, from http://www.li.lv/index.php?option=com_content\&task=view\&id=74\&Itemid= 


\section{6}

Creswell, J. (1998). Qualitative inquiry and research design: Choosing among five traditions. Thousand Oaks, CA: Sage.

Čehlovs, M., \& Čehlova, Z. (2009). Skolotāju pedagoǵiskās kompetences teorētiskie pamati [Theoretical basis of teachers' pedagogical competence]. In I. Žogla (Ed.), Latvijas Universitātes raksti: Pedagogija un skolotāju izglītība [Collected articles of the University of Latvia: Pedagogy and teacher education]. Volume 747, Rīga: Latgales druka, 57-63.

Dauge, A. (1928). Audzināšanas ideāls un īstenība [Ideal and reality of upbringing]. Cēsis, Rīga: Jepe.

Dāle, P. (1939). Gara problēmas [Problems of the spirit]. Rīga: Valters un Rapa.

Elliot, J. (1993). Reconstructing teacher education. London: Falmer Press.

Elliot, J (2002). The paradox of educational reform in the evaluatory state: Implications for teacher education. Prospects, 32(3), 273-287.

Elliot, J., \& Kushner, S. (2007). The need for a manifesto for educational programme evaluation. Cambridge Journal of Education, 37(3), 321-336.

Fairclough, N. (2000). Discourse, social theory, and social research: The discourse of welfare reform. Journal of Sociolinguistics, 4(2), 163-195.

Gallegos-Nava, R. (2001). Holistic education: Pedagogy of universal love. Brandon, VT: Foundation for Educational Renewal.

Gardner, H. (2000). Intelligence reframed: Multiple intelligences for the 21 st century. New York: Basic Books.

Geidžs, N., \& Berliners, D. (1999). Pedagoǵiskā psihologija [Pedagogical psychology]. Riga: Zvaigzne ABC.

Goleman, D. (1995). Emotional intelligence. New York: Bantam.

Goḷdina, A. (2003, January 8). Dzīvesstāsts [Life story], recorded by Kvedere, Z., stored in DU COH: 12.

Grīnberga, E. (2002, January 9). Dzīvesstāsts [Life story], recorded by Maslova, O., stored in DU COH: 15.

Hiden, J., \& Salmon, P. (1991). The Baltic nations and Europe: Estonia, Latvia and Lithuania in the twentieth century. London and New York: Longman.

Izglītības Ministrijas Mēnešraksts [Ministry of Education Monthly] (1921). Rīga: Latvijas skolotāju kongress, No. 2 (pp. 130-139). Retrieved October 13, 2010 from http://www.liis.lv/latval/Valoda/Teksts/3nodalja/Citati/10.htm

Lieǵeniece, D. (2009). Bērna uzvedības problēmu cēloṇi: Rietumvalstīs veiktu pētījumu analīze [Causes of children's behavioural problems: Analysis of Western studies]. In I. Žogla (Ed.), Latvijas Universitātes raksti:Pedagogija un skolotāju izglītība [Collected articles of the University of Latvia: Pedagogy and teacher education] (pp. 124-133). Volume 747. Rìga: Latgales druka.

Likums par tautas izglìtību [Law on the Nation's Education]. (1921). Latvian State Historical Archives, Fund 1632, Description 2, Case 24.

Maslo, I. (2006). Mācīšanās daudzveidības izpratne integratīvo procesu teorijā. [Understanding of learning diversity in the theory of integrative processes]. In I. Maslo (Ed.), No zināšanām un kompetentu darbību: Mācīšanās antrpologiskie, ètiskie un 
sociālkritiskie aspekti [From knowledge to competent activity: Anthropological, ethical, and social-critical aspects of learning] (pp. 20-44). Rīga: LU Akadēmiskais apgāds.

Mayer, J., Salovey, P., Caruso, D., \& Sitarenios, G. (2003). Measuring and modeling emotional intelligence with the MSCEIT V 2.0. Emotion, 3, 97-105.

Mayer, J., Salovey, P., \& Caruso, D. (2004). Emotional intelligence: Theory, findings, and implications. Psychological Inquiry, 15, 197-215.

Mezirow, J. (1991). Transformative dimensions of adult learning. San Francisco: JosseyBass.

Mezirow, J. (2000). Learning as transformation: Critical perspectives on a theory in progress. San Francisco: Jossey-Bass.

Noddings, N. (2003). Happiness and education. Cambridge: Cambridge University Press.

O'Sullivan, E. (2001). Transformative learning: Educational vision for the $21^{\text {st }}$ century. London: Zed.

Pētersons, E. (1931). Vispārīgā didaktika [General didactics]. Rīga: A. Gulbjis.

Pētersons, A. (1938). Paidagoǵiskā mīlestîba [Pedagogical love]. Latvian State Historical Archives, Fund 1632, Description 2, Case 1346.

Pētersons, E. (n.d.a). Dz̄ives līizsvars pedagogikā [Life balance in pedagogy]. Latvian State Historical Archives, Fund 1632, Description 2, Case 1346.

Pētersons, E. (n.d.b). Skolas un skolotāja autoritāte [School and teacher's authority]. Latvian State Historical Archives, Fund 1632, Description 2, Case 1346.

Pētersons, E. (n.d.c). Par skolotāju profesijas sociolog̣iju un psihologiju [On the sociology and psychology of teacher's profession]. Latvian State Historical Archives, Fund 1632, Description 2, Case 1346.

Pipere, A. (2007). Becoming a researcher: Interplay of identity and sustainability. In A. Pipere (Ed.), Education and Sustainable Development: First Steps toward Changes (Vol. 2, pp. 241-262). Daugavpils: Daugavpils University Publishing House "Saule".

Ratnieks, J. (1940). Skolotājs sabiedriskā darba laukā [Teacher in the field of public work]. Latvian State Historical Archives, Fund 1632, Description 2, Case 1346.

Rimša, R. (2002, Nowember 30). Dzīvesstāsts [Life story], recorded by Līvma, I., stored in DU COH: 14.

Rutka, L. (2009). Pedagoga psihologiskā kompetence [Educator's psychological competence]. In I. Žogla (Ed.), Latvijas Universitātes raksti:Pedagogija un skolotāju izglìtỉba [Collected articles of the University of Latvia: Pedagogy and teacher education] (Vol. 747, pp. 170-182). Rīga: Latgales druka.

Salīte, I., Mičule, I., Kravale, M., Iliško, Dz., \& Stakle, A. (2007). Toward the sustainability in teacher education: Promise of action research. In A. Pipere (Ed.), Education and Sustainable Development: First Steps toward Changes (Vol. 2, pp. 263-292). Daugavpils: Daugavpils University Publishing House "Saule".

Salowey, P., \& Mayer, J. (1990). Emotional Intelligence. Imagination, Cognition and Personality, 9, 176-194.

Sheri, R.. (2008). Holistic reflection in teacher education: Issues and strategies. Reflective Practice, 9(2), 111-121. 
Sherman, S. (2004). Responsiveness in teaching: Responsibility in its most particular sense. The Educational Forum, 68(2), 115-125.

Storbeck, J., \& Clore, G. (2007). On the interdependence of cognition and emotion. Cognition \& Emotion, 21(6), 1212-1237.

Students, J., A. (1933). Vispārīgā paidagog̣ija [General pedagogy]. Rīga: Fr. Baumaņa apgāds.

Šeimans J. (2003, January 9). Dzīvesstāsts [Life story], recorded by Ašaka, A., stored in DU COH: 19.

Štāls, M. (1927). Audzināšana un mācǐšana agrā bērnībā [Early childhood upbringing and teaching]. Rīga: Valters \& Rapa.

Vīķe-Freiberga, V. (2010). Kultūra un latvietība [Culture and Latvianness]. Rìga: Karogs.

Van Manen, M. (2002). The tone of teaching. London: Althouse Press.

Wilber, K. (1997). An integral theory of consciousness. Journal of Consciousness Studies, 4, 71-92.

Wilber, K., Patten T., Leonard, A., \& Morelli, M. (2008). Integral life practice: A $21^{\text {st }}$ century blueprint for physical health, emotional balance, mental clarity, and spiritual awakening. London: Integral Books.

Zeichner, K., Melnick, S., \& Gomez, M. (1996). Currents of reform in preservice teacher education. New York: Teachers College Press.

Žukovs, L., \& Kopeloviča, A. (1997). Pedagogiskā doma Latvijā [Pedagogical thought in Latvia]. Rīga: RaKa.

\section{Correspondence:}

Inga Belousa, $\mathrm{PhD}$, Institute of Sustainable Education, Faculty of Education and Management, Daugavpils University, Parādes Street 1-432, Daugavpils, LV-5401, Latvia. Tel.: + 371654 27411. Email: inga.belousa@du.lv 